\title{
The Effectiveness of Neem Cake (Azadirachta indica) Water Extract against Aphids (Aphis gossypii) on Red Chili Plant
}

\author{
Lathifah Azizah ${ }^{1}$, Ceppy $\operatorname{Nasahi}^{2} \&$ Danar Dono $^{2 *}$ \\ ${ }^{1}$ Alumny of Plant Pests and Diseases Department, Agriculutre Faculty, Universitas Padjadjaran, Jatinangor, West Java, \\ Indonesia. 45363 \\ ${ }^{2}$ Department of Plant Pests and Diseases, Agriculutre Faculty, Universitas Padjadjaran, Jatinangor, West Java, Indonesia. \\ 45363 \\ *Corresponding Author : danar.dono@unpad.ac.id
}

Received November 17, 2021; revised December 21, 2021; accepted December 22, 2021

\begin{abstract}
Aphis gossypii is one of the factors that reduce chili production which acts as a pest and virus vector. This research aimed to determine the effectiveness of the application of neem cake water extract to A. gossypii on red chili plants. This research consisted of 2 experimental stages, namely in the laboratory and the greenhouse trials. The experimental design in the laboratory used a completely randomized design of neem cake water extract with treatments is A (Control), B $(0.3 \%), \mathrm{C}$ $(0.6 \%), \mathrm{D}(1.2 \%), \mathrm{E}(2.4 \%), \mathrm{F}(4.8 \%)$. Each treatment replicate 4 times. Aplication of water neem cake extract by dipping method of chilli leaf. After the leaf feed air dried, then the leaf put into plastic box and invested with 10 nymph of $A$. gossypii. While the experiments in the greenhouse used a randomized block design of neem cake water extract treatments were A (Control), B $\left(\mathrm{LC}_{50}\right), \mathrm{C}\left(1.5 \mathrm{xLC}_{50}\right), \mathrm{D}\left(2 \mathrm{xLC}_{50}\right), \mathrm{E}\left(2.5 \mathrm{xLC}_{50}\right), \mathrm{F}\left(3 \mathrm{xLC}_{50}\right)$. The concentration of neem extract in the greenhouse experiment based on result of experiment at laboratory. Adults of A. gossypii as much as 20 were invested on every red chili plant. Application of neem cake water extract on red chili plants once every 4 days. The results showed that neem cake water extract effective to A. Gossypii with $0.14 \%$ as $\mathrm{LC}_{50}$. Neem cake water extract at concentration of $1.5 \mathrm{xLC}_{50}$ $(0.21 \%)$ was effective suppressing A. gossypii population on red chili plants.
\end{abstract}

Keywords: Lethal Concentration, Mortality, Aphis gossypii, Effectiveness.

\section{ABSTRAK}

\section{Keefektifan Ekstrak Air Bungkil Biji Mimba (Azadirachta indica) terhadap Kutu Daun (Aphis gossypii) pada Tanaman Cabai Merah}

Aphis gossypii merupakan salah satu faktor penurun produksi cabai yang berperan sebagai hama dan vektor virus. Penelitian bertujuan mengetahui efektifitas aplikasi ekstrak air bungkil biji mimba terhadap A. gossypii pada tanaman cabai merah. Penelitian ini terdiri dari 2 tahap percobaan yaitu di laboratorium dan rumah kaca. Sebagai perlakuan percobaan di laboratorium yaitu ekstrak air bungkil biji mimba dengan 5 taraf konsentrasi dan satu kontrol yang di ulang 4 kali. Masingmasing perlakuan yaitu A (Kontrol, $0,0 \%), \mathrm{B}(0,3 \%), \mathrm{C}(0,6 \%), \mathrm{D}(1,2 \%), \mathrm{E}(2,4 \%), \mathrm{F}(4,8 \%)$ yang diaplikasikan dengan pencelupan daun tanaman cabe dalam larutan ekstrak. Setelah ekstrak pada daun kering angin, kemudian daun tersebut dimasukkan ke dalam wadah plastik selanjutnya diinvestasi nimfa A. Gossypii sebanyak 10 ekor. Hubungan konsentrasi ekstrak dengan mortalitas serangga uji dianalisis probit untuk mendapatkan nilai Lethal Concentration (LC). Sebagai perlakuan percobaan di rumah kaca menggunakan 5 taraf konsentrasi ekstrak bungkil biji mimba yaitu A (Kontrol), B $\left(\mathrm{LC}_{50}\right), \mathrm{C}\left(1,5 \mathrm{xLC}_{50}\right), \mathrm{D}\left(2 \mathrm{xLC}_{50}\right), \mathrm{E}\left(2,5 \mathrm{xLC}_{50}\right), \mathrm{F}\left(3 \mathrm{xLC}_{50}\right)$ yang diperoleh dari hasil percobaan laboratorium. Masingmasing perlakuan diulang 4 kali. Setelah tanaman disemprot masing-masing larutan ekstrak menggunakan hand sprayer dan larutan telah kering angina, kemudian 20 imago A. gossypii diinvestasikan pada tanaman cabai merah. Aplikasi larutan ekstrak dilakukan setiap 4 hari sekali. Hasil penelitian menunjukkan ekstrak air bungkil biji mimba efektif terhadap $A$. Gosypii dengan nilai $\mathrm{LC}_{50}$ sebesar $0,14 \%$ serta perlakuan $1,5 \mathrm{xLC}_{50}(0,21 \%)$ efektif menekan populasi A. gossypii pada tanaman cabai merah.

Kata Kunci: Lethal Concentration, Mortalitas, Aphis gossypii, Keefektifan

\section{PENDAHULUAN}

Kutu daun Aphis gossypii Glover (Homoptera: Aphididae) merupakan organisme pengganggu tanaman (OPT) penting di daerah tropis maupun subtropis. Kutu daun ini tergolong hama yang memiliki banyak inang (polifag) diantaranya cabai, terung, tomat, semangka, melon, timun, buncis, kacang panjang, jeruk, nilam, rosella, wijen, dan kapas (Purwanto, 2017). Dari beberapa tanaman inang tersebut kutu daun banyak menyerang tanaman cabai. Cabai merupakan salah satu komoditas hortikultura penting di Indonesia, namun produktivitasnya masih tergolong rendah yaitu sekitar 8,77 ton/Ha (BPS, 2018), walaupun pada rentang tahun 2015 hingga 2017 luas panen cabai merah besar selalu bertambah (BPS dan Direktorat Jendral Hortikultura, 2018).

A. gossypii pada saat populasinya tidak terkendali dapat menyebabkan kerusakan tanaman 
cabai hingga mencapai $65 \%$, tingkat kerusakan mulai dari fase bibit hingga dewasa (Daryanto et al., 2017). Populasi yang tidak terkendali A. gossypii menyebabkan klorosis, nekrosis, pengkerdilan, layu, gugurnya bunga dan buah, serta distorsi dan defoliasi pada daun (da Costa et al., 2011). Kutu daun selain sebagai hama, berperan juga sebagai vektor yang efektif dalam menularkan virus tanaman serta mampu menularkan lebih dari 160 virus yang berbeda, virus yang ditularkan oleh kutu daun kebanyakan menyebabkan penyakit mosaik, beberapa menghasilkan jenis penyakit kuning (Nurhayati, 2012).

Kutu daun sebagai vektor dapat mengakibatkan kerugian lebih dari $90 \%$ sedangkan sebagai hama 6-25\% (Miles, 1987; Khodijah, 2014). Telah dilaporkan bahwa 76 virus penyebab penyakit pada berbagai jenis tumbuhan disebabkan oleh kutu daun (Satar et al, 1999). Hingga saat ini, pengendalian yang dilakukan masih berbasis bahan kimia sintetik berupa insektisida. Oleh karena itu banyak laporan menyebutkan bahwa $A$. gossypii telah resisten terhadap berbagai jenis insektisida kimiawi sintetis (George et al., 2019).

Kebutuhan terhadap pestisida sintetik sebagai pengendali hama dan penyakit pada tanaman perlu diimbangi dengan penggunaan yang sesuai untuk meminimalisir dampak negatif dari penggunaannya. Hal ini perlu dilakukan mengingat produk pertanian merupakan salah satu sumber makanan bagi kebutuhan manusia. Ketergantungan pada penggunaan pestisida sintetik mengakibatkan konsumsi pestisida sintetik yang tidak terkendali, sehingga produk pertanian cenderung memiliki residu pestisida yang memiliki dampak buruk bagi kesehatan manusia. Salah satu upaya untuk mengatasi hal tersebut, yaitu menggalakkan program penggunaan pestisida nabati.

Pestisida nabati merupakan alternatif dalam penggunaan pestisida sintetik karena pestisida nabati memiliki beberapa keuntungan yakni daya kerja yang selektif, residu cepat terurai, tidak beracun, tidak menimbulkan pencemaran (air, tanah, udara dan tanaman), serangga berguna atau musuh alami tidak ikut musnah, serangga tidak mengalami resistensi (Balai Pengkajian Teknologi Pertanian Kalimantan Tengah, 2011). Koch et al. (2018) menyebutkan bahwa strategi untuk meminimalisasi perkembangan serangga resisten salah satunya dengan menggunakan insektisida alternatif yang berbeda kelompoknya, termasuk menggunakan insekktisida nabati. Oleh karena itu, pestisida nabati seharusnya dapat menjadi pilihan para petani untuk beralih dari pestisida sintetik ke pestisida nabati.

Salah satu tanaman yang dapat dimanfaatkan sebagai pestisida nabati yaitu tanaman mimba (Azadirachta indica). Senyawa aktif dari tanaman ini dilaporkan efektif terhadap sedikitnya 300 spesies serangga hama (Samsudin, 2011). Salah satu kandungan kimia tanaman tersebut yaitu azadirakhtin yang sudah sejak lama digunakan sebagai insektisida nabati. Senyawa azadirachtin paling banyak ditemukan pada bagian biji mimba (Palupi et al., 2016). Senyawa azadirakhtin memiliki berbagai aktivitas hayati diantaranya penghambatan pertumbuhan dan perkembangan serangga hama, aktivitas antifidan, penghambat produksi dan penetasan telur, infertilitas, serta gangguan hormonal serangga (Dhra et al., 2018).

Minyak mimba yang banyak digunakan sebagai bahan baku insektisida nabati diperoleh dari ekstraksi biji buah mimba dengan teknik pengepresan. Dari proses pengepresan tersebut menghasilkan limbah berupa bungkil biji mimba. Namun, bungkil biji mimba yang yang merupakan limbah dari hasil pengekstrakan biji mimba masih minim digunakan sebagai insektisida nabati. Di India $40 \mathrm{~kg}$ buah menghasilkan $24 \mathrm{~kg}$ buah kering $(60 \%)$, yang menghasilkan 11,52 kg bubur (48\%), 1,1 kg kulit biji (4,5\%), $6 \mathrm{~kg}$ sekam (25\%) dan 5,5 kg inti biji (23\%). Inti biji menghasilkan $2,5 \mathrm{~kg}$ minyak mimba (45\%) dan 3,0 kg bungkil biji (55\%) (Koul et al., 1990). Dari perbandingan inti biji tersebut, $55 \%$ bungkil biji mimba minim digunakan karena belum diketahui penggunaannya secara luas, khususnya sebagai insektisida nabati. Oleh karena itu, diperlukan pengembangan terhadap bungkil biji mimba agar dapat digunakan kembali.

Biji mimba yang diekstrak menggunakan air efektif mengendalikan A. gossypii karena menyebabkan mortalitas yang tinggi, mengurangi periode kelangsungan hidup, serta fekunditas (dos Santos et al., 2004). Beberapa hasil penelitian telah menunjukkan penggunaan bungkil biji mimba dapat memberikan efek terhadap serangga hama. Ekstrak air bungkil biji mimba pada konsentrasi $10 \%$ menunjukkan efek repellent terhadap Lipaphis erysimi $66,67 \%$ dan meningkat menjadi $97,92 \%$ setelah 48 hingga 72 jam pada tanaman kanola (Brassica napus L.) (Aziz et al, 2014). Ekstrak bungkil biji mimba juga dilaporkan efektif terhadap Spodoptera frugiperda dengan nilai $\mathrm{LC}_{50}$ sebesar $0,13 \%$ (Silva et al, 2015). Namun, masih minim informasi mengenai penggunaan ekstrak air bungkil biji mimba untuk mengendalikan kutu daun $A$. gossypii pada tanaman cabai merah, sehingga diperlukan pengujian tersebut.

\section{BAHAN DAN METODE}

\section{Waktu dan Tempat Percobaan}

Penelitian dilaksanakan pada bulan Mei 2019 sampai November 2019. Percobaan uji toksisitas ekstrak air bungkil biji mimba dilaksanakan di Laboratorium Pestisida dan Toksikologi Lingkungan Departemen Hama dan Penyakit Tumbuhan sedangkan percobaan uji keefektifan ekstrak air bungkil biji mimba dilaksanakan di Rumah Kaca Ciparanje, Fakultas Pertanian, Universitas Padjadjaran, Jatinangor. 


\section{Penanaman Cabai}

Cabai yang digunakan adalah cabai varietas Unpad CB2 (Lampiran 2). Benih terlebih dahulu direndam dengan air selama 24 jam kemudian ditiriskan. Selanjutnya dilakukan seleksi benih yang baik yaitu benih yang tenggelam. Benih disemai pada nampan yang telah terisi media tanam (tanah dan pupuk kandang) dengan perbandingan 2:1.

Penyemaian dilakukan selama 28 hari dengan penyiraman setiap dua hari sekali pada pagi hari. Bibit cabai hasil penyemaian yang sehat berumur 4 MST (minggu setelah tanam) dan telah mempunyai 3-4 helai daun yang tidak terserang atau terinfeksi oleh hama-penyakit, dipindah tanamkan ke dalam polybag yang berukuran $30 \mathrm{~cm} \times 15 \mathrm{~cm}$. Setelah tanaman berumur 5 MST maka tanaman cabai siap untuk perlakuan.

\section{Perbanyakan Aphis gossypii}

Serangga uji yang digunakan yaitu imago kutu daun yang tidak bersayap dari tanaman cabai yang didapat dari Kebun Percobaan Ciparanje. Imago diidentifikasi untuk memastikan bahwa serangga uji yang adalah kutu daun A. gossypii. Identifikasi berdasarkan pada kunci identifikasi kutu daun dari Blackman and Eastop (2000). Identifikasi dilakukan dengan cara pembuatan preparat slide dari sampel serangga uji. Karakter kutu daun yang diidentifikasi adalah bentuk antena, tuberkel, kornikel, serta kauda.

Kutu daun A. gossypii diperbanyak pada tanaman cabai yang sudah memiliki minimal 6 daun. Pemindahan kutu daun dari tanaman yang terinfestasi kutu daun ke tanaman perbanyakan dengan memotong bagian tanaman terserang seperti batang atau daun lalu diletakkan di tanaman perbanyakan yang sudah berada dalam kurungan dan kutu daun akan berpindah ke daun yang lebih segar. Serangga hasil perbanyakan digunakan untuk percobaan dengan cara diinvestasikan pada tanaman cabai yang sudah berumur \pm 14 HST (hari setelah tanam). Cabai ditanam pada polibag yang ditutup dengan kain kasa dan diletakkan di rumah kaca.

\section{Pelaksanaan Percobaan}

\section{Percobaan 1. Toksisitas Ekstrak Air Bungkil Biji Mimba terhadap A. gossypii}

Uji pendahuluan dilakukan untuk mencari batas atas serta batas bawah konsentrasi dari ekstrak air bungkil biji mimba yang mengakibatkan mortalitas serangga uji antara $0 \%<\mathrm{x}<100 \%$. Perlakuan kontrol hanya menggunakan larutan dengan konsentrasi $0,01 \%$ Tween 80 . Pembuatan ekstrak air bungkil biji mimba, misalkan konsentrasi $1 \%$, dibuat dalam gelas piala yang terdiri dari $1 \mathrm{~g}$ serbuk bungkil biji mimba kemudian ditambahkan pelarut, diaduk dan dibiarkan selama 30 menit. Selanjutnya bungkil disaring dengan kertas saring, ampas dibilas dengan pelarut hingga volume akhir $100 \mathrm{ml}$. Pengukuran volume akhir larutan dilakukan menggunakan labu takar $100 \mathrm{ml}$.
Larutan ekstrak air bungkil mimba yang diperoleh digunakan untuk pengujian dengan cara pencelupan pakan. Konsentrasi lainnya dibuat mengikuti prosedur yang sama.

Pakan yang digunakan daun cabai dengan batang daun dibalut oleh kapas yang telah dibasahi kemudian ditutup plastik wrap agar pakan tidak cepat kering. Pakan tersebut kemudian dicelupkan pada konsentrasi larutan yang berbeda dan kontrol. Pakan dicelupkan ke dalam larutan hingga seluruh bagian daun terbasahi oleh larutan ekstrak. Pencelupan dilakukan selama 10 detik yang dihitung dengan stopwatch. Pakan yang telah dicelupkan, kemudian diletakkan di atas kertas tissue lalu dikering anginkan. Pakan yang telah kering angin dimasukkan ke dalam wadah plastik berukuran $11 \mathrm{~cm} \times 9 \mathrm{~cm}$ x $5 \mathrm{~cm}$. Jumlah pakan yang dimasukkan ke dalam tiap wadah sebanyak dua helai daun dengan lebar 2-3 cm dengan perlakuan yang sama.

Nimfa kutu daun A. gossypii instar III digunakan sebagai serangga uji. Cara investasi serangga uji yaitu dengan cara pemindahan dari kotak pemeliharaan menggunakan kuas halus ke dalam cawan petri yang telah diberi alas kertas tissue. Pemindahan serangga uji sebanyak 10 nimfa/wadah yaitu diletakkan diatas daun cabai serta dipastikan bahwa nimfa dalam keadaan hidup. Pengamatan dilakukan setiap hari hingga nimfa mencapai imago yang dilakukan dengan selang waktu pengamatan 24 jam. Setelah pemberian pakan selama 48 jam, daun pakan yang telah diberi perlakuan diganti dengan daun pakan tanpa perlakuan. Selanjutnya penggantian pakan tanpa perlakuan dilakukan setiap hari hingga nimfa mencapai imago. Peubah yang diamati pada uji pendahuluan yaitu mortalitas nimfa.

Berdasarkan hasil uji pendahuluan bahwa konsentrasi batas bawah sebesar $0,3 \%$ dan batas atas sebesar 4,8\%. Penghitungan besaran selang konsentrasi tersebut dihitung menggunakan rumus deret geometri berikut:

Dimana :

$$
\mathrm{F}=\sqrt[n-1]{\frac{B A}{B B}}
$$

$$
\begin{array}{ll}
\mathrm{F} & : \text { Faktor pengali kenaikan konsentrasi } \\
n & : \text { Jumlah konsentrasi } \\
B A & : \text { Batas atas konsentrasi } \\
B B & : \text { Batas bawah konsentrasi }
\end{array}
$$

Uji lanjutan dilakukan untuk mengetahui toksisitas relatif ekstrak air bungkil biji mimba yang mengakibatkan mortalitas serangga uji. Prosedur pengujian pada uji lanjutan sama seperti pada uji pendahuluan. Konsentrasi ekstrak diuji pada 5 taraf konsentrasi yang diperoleh berdasarkan uji pendahuluan. Percobaan disusun dalam rancangan Acak Lengkap (RAL) dengan pengulangan sebanyak 4 kali. Pengamatan dilakukan terhadap mortalitas serangga uji. Hubungan konsentrasi dengan mortalitas serangga uji dianalisis dengan analisis probit menggunakan program Polo. 


\section{Percobaan 2. Keefektifan Ekstrak Air Bungkil Biji Mimba terhadap A. gossypii \\ Perlakuan pada Percobaan 2 terdiri atas} kelipatan nilai $\mathrm{LC}_{50}$ yang diperoleh dari hasil Percobaan 1. yaitu $\mathrm{LC}_{50}, 1,5 \mathrm{xLC}_{50}, 2 \mathrm{xLC}_{50}, 2,5 \mathrm{xLC}_{50}$, $3 \mathrm{xLC}_{50}$, dan kontrol. Tanaman cabai merah varietas Unpad CB2 yang telah berumur 6 MST sebelum aplikasi diinvestasi terlebih dahulu masing-masing 20 imago/polybag menggunakan kuas halus dan ditutup dengan sungkup serta diletakkan di rumah kaca. Kutu daun dibiarkan beradaptasi selama 4 hari. Setelah itu, dilakukan aplikasi insektisida sesuai dengan perlakuan. Pengamatan populasi dilakukan pada sebelum dan sesudah aplikasi.

Aplikasi larutan ekstrak pada tanaman uji menggunakan handsprayer kapasitas $100 \mathrm{ml}$ yang dilakukan sebanyak 4 kali selama pengujian. Percobaan disusun dalam rancangan Acak Kelompok yang diulang 4 kali. Parameter yang diamati yaitu populasi kutu daun A. gossypii dan intensitas kerusakan daun.

Populasi kutu daun diamati setiap hari hingga hari ke-15 setelah aplikasi. Pengamatan dilakukan dengan cara menghitung jumlah populasi A. gossypii. Data populasi dianalisis dengan sidik ragam (ANOVA) dan uji lanjut jarak berganda Duncan pada taraf nyata 5\% untuk membandingkan setiap perlakuan. Analisis dilakukan menggunakan program SPSS versi 21.

Intensitas kerusakan daun dihitung pada 7 HSA dan 14 HSA. Kerusakan dinilai berdasarkan gejala serangan yang muncul seperti daun yang mengeriting, nekrosis dan rontok. Intensitas kerusakan daun dihitung menggunakan rumus (Walker, 1991).

$$
\mathrm{P}=\frac{\sum n \times v}{Z \times N} \times 100 \%
$$

Dimana :

$$
\begin{aligned}
& \mathrm{P}: \text { Intensitas kerusakan daun }(\%) \\
& \mathrm{n}: \text { Jumlah daun yang diamati dengan } \\
& \text { kategori sama } \\
& \mathrm{v}: \text { Nilai skor dari tiap kategori serangan } \\
& \mathrm{N}: \text { Jumlah daun keseluruhan } \\
& \mathrm{Z}: \text { Nilai skor tertinggi }
\end{aligned}
$$

Nilai kategori untuk masing-masing serangan sebagai berikut :

$0=$ Sampel tidak terserang sama sekali

$1=$ Serangan $0 \%<\mathrm{x}_{1} \leq 20 \%$ luas daun

$2=$ Serangan $20 \%<\mathrm{x}_{2} \leq 40 \%$ luas daun

$3=$ Serangan $40 \%<\mathrm{x}_{3} \leq 60 \%$ luas daun

$4=$ Serangan $60 \%<\mathrm{x}_{4} \leq 80 \%$ luas daun

$5=$ Serangan $x_{5}>80 \%$ luas daun

Pengamatan penunjang yang dilakukan yaitu fitotoksisitas yang muncul pada tanaman cabai merah akibart aplikasi insektisida. Pengamatan dilakukan setiap hari.

\section{HASIL DAN PEMBAHASAN}

\section{Toksisitas Ekstrak Air Bungkil Biji Mimba terhadap A. gossypii}

Ekstrak air bungkil biji mimba mengakibatkan mortalitas nimfa A. gossypii. Mortalitas serangga uji semakin meningkat dengan semakin tingginya konsentrasi ekstrak yang diaplikasikan dan seiring dengan bertambahnya hari (Gambar 1).

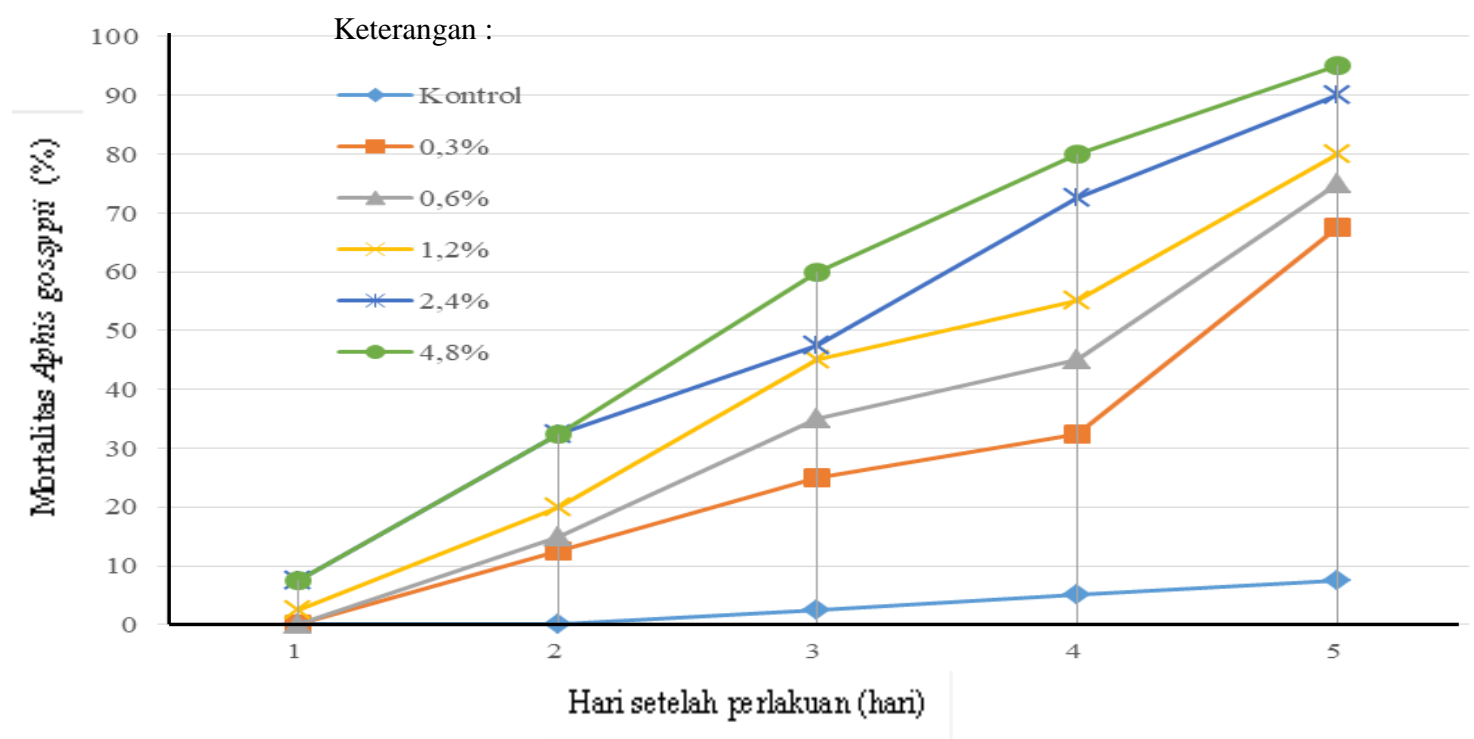

Gambar 1. Mortalitas nimfa Aphis gossypii pada berbagai taraf konsentrasi ekstrak air bungkil biji mimba.

Berdasarkan hasil analisis probit menunjukkan bahwa hasil nilai LC menurun mulai dari 1 HSA hingga 5 HSA. Perubahan nilai LC yang semakin kecil mengindikasikan bahwa semakin banyak serangga uji yang mati sejalan dengan pertambahan hari. Analisis probit pada hari kelima setelah 
perlakuan menunjukkan $\mathrm{LC}_{50}$ yang cukup rendah $(0,14 \%)$ yang mengindikasikan bahwa ekstrak air bungkil biji mimba memiliki toksisitas tinggi terhadap A. gossypii (Tabel 1).

Nimfa A. gossypii yang mati disebabkan pengaplikasian ekstrak air bungkil biji mimba memperlihatkan ciri bagian tubuh mengering dan berwarna merah kecoklatan.

Mortalitas nimfa A. gossypii disebabkan oleh zat aktif pada ekstrak air bungkil biji mimba yaitu azadirakhtin yang mampu bertindak sebagai antifidan, ecdyson blocker, serta gangguan perkembangan dan reproduksi serangga (Dewi et al., 2017). Senyawa aktif Azadirakhtin berspektrum lebar, aktivitas pada tingkat fisiologi dapat mengakibatkan penurunan kadar hormon PPTH, menghambat saluran Calsium serta, mengganggu reseptor kimiawi, mepengaruhi enzim pencernaan, mengakibatkan apoptosis sel, mengganggu sintesis protein mengganggu proses metabolik protein gen. Azadirakhtin digunakan untuk pengendalian berbagai serangga hama pertanian meliputi ordo Coleoptera, Hemiptera, Diptera, Orthoptera, dan Isoptera (Kilani-Morakchi et al 2021).

Tabel 1. Parameter regresi probit toksisitas ekstrak air bungkil biji mimba terhadap Aphis gossypii berdasarkan waktu.

\begin{tabular}{cccccccc}
\hline Waktu & $\mathrm{a} \pm \mathrm{SE}$ & $\mathrm{b} \pm \mathrm{SE}$ & $\mathrm{LC}_{50}(\%)$ & $\mathrm{SK}_{95 \%}(\%)$ & $\mathrm{LC}_{95}(\%)$ & $\mathrm{SK}_{95 \%}(\%)$ & $\mathrm{g}$ \\
\hline 1 HSA & $3,16 \pm 0,29$ & $1,30 \pm 0,58$ & 47,44 & - & 890,39 & - & 0.770 \\
2 HSA & $4,84 \pm 0,10$ & $0,66 \pm 0,24$ & 18,73 & - & 5927,40 & - & 0,511 \\
3 HSA & $4,30 \pm 0,11$ & $0,74 \pm 0,23$ & 2,50 & $1,349-9,189$ & 405,26 & $45,560-0,192$ & 0,355 \\
4 HSA & $5,42 \pm 0,11$ & $1,16 \pm 0,24$ & 0,92 & $0,528-1,402$ & 24,34 & $9,624-201,772$ & 0,168 \\
& & & & & & & \\
5 HSA & $5,84 \pm 0,11$ & $0,98 \pm 0,27$ & 0,14 & $0,011-0,313$ & 6,70 & $2,940-84,248$ & 0,304 \\
\hline
\end{tabular}

\begin{tabular}{ll}
\hline Keterangan & : \\
HSA & Hari setelah aplikasi \\
$\mathrm{a}$ & : Intersep garis regresi \\
$\mathrm{b}$ & : Kemiringan garis regresi (slope) \\
$\mathrm{SE}$ & $:$ Standard Error \\
$\mathrm{LC}$ & $:$ Lethal concentration \\
$\mathrm{SK}$ & $:$ Selang kepercayaan \\
$\mathrm{g}$ & : Tingkat ketelitian penduga
\end{tabular}

Keefektifan Ekstrak Air Bungkil Biji Mimba terhadap A. gossypii

Populasi A. gossypii pada 1 HSA hingga 5

HSA menunjukkan hasil tidak berbeda nyata. Pada hari tersebut populasi A. gossypii mengalami peningkatan. Penurunan mulai terlihat pada hari 7 HSA. Kemudian, hingga 15 HSA populasi A. gossypii masih fluktuatif (Tabel 2). Namun pada 5 HSA, 10 HSA, dan 15 HSA jumlah populasi mengalami penurunan. Rendahnya mortalitas akibat aplikasi ekstrak air bungkil biji mimba disebabkan bahwa penggunaan pestisida nabati membutuhkan waktu lebih lama dibandingkan penggunaan pestisida sintetik. Hal ini sesuai berdasarkan penelitian Dewi et al. (2017), penggunaan pestisida nabati dari mimba dapat menyebabkan kematian seketika ataupun kematian secara bertahap terhadap serangga hama, namun memerlukan waktu (4 hingga 5 hari) agar bahan kimia tersebut dapat menimbulkan efek kematian bagi serangga hama. Namun demikian, hama yang telah terpapar pestisida nabati daya rusaknya telah menurun karena dalam keadaan sakit.

Penurunan populasi menunjukkan hasil berbeda nyata pada 6 HSA, bahwa perlakuan
$1,5 \mathrm{xLC}_{50}, 2 \mathrm{xLC}_{50}, 2,5 \mathrm{xLC}_{50}$, dan $3 \mathrm{xLC}_{50}$ berbeda nyata dengan perlakuan kontrol namun tidak berbeda nyata antar perlakuan. Hasil tersebut sama seperti 8 HSA dan 9 HSA. Sedangkan pada 10 HSA hingga 15 HSA semua perlakuan berbeda nyata terhadap kontrol namun tidak berbeda nyata antar perlakuan.

Kepadatan populasi yang relatif meningkat diduga makanan yang tersedia dalam jumlah yang cukup berupa daun tanaman cabai merah yang masih muda serta lunak. Jumar (2000) menyebutkan jika, makanan tersedia dengan kualitas serta kuantitas yang cukup dan cocok maka populasi serangga akan naik dengan cepat. Saat percobaan pada tanaman cabai merah tidak ditemukan imago A. gossypii yang bersayap, hal ini diduga makanan yang masih tersedia dengan jumlah yang cukup. Kalshoven (1981) menyebutkan bahwa jika jumlah makanan tersedia banyak maka bentuk tidak bersayap lebih banyak ditemukan daripada bentuk bersayap. Selain faktor makanan, faktor lingkungan juga sangat besar pengaruhnya terhadap pertumbuhan serta perkembangan populasi dari kutu daun. 
Tabel 2. Populasi Aphis gossypii pada tanaman cabai merah

\begin{tabular}{|c|c|c|c|c|c|c|c|c|}
\hline \multirow{3}{*}{ Perlakuan } & \multicolumn{8}{|c|}{ Rata-rata populasi Aphis gossypii (ekor/tan) pada HSA } \\
\hline & \multicolumn{2}{|c|}{$\begin{array}{c}\text { Aplikasi ke-1 } \\
0^{\operatorname{tn}}\end{array}$} & \multicolumn{2}{|c|}{$1^{\text {tn }}$} & \multicolumn{2}{|c|}{$2^{\mathrm{tn}}$} & \multicolumn{2}{|c|}{$3^{\operatorname{tn}}$} \\
\hline & $(\mathrm{X} \pm \mathrm{SE})$ & $\mathrm{PP}$ & $(\mathrm{X} \pm \mathrm{SE})$ & PP & $(\mathrm{X} \pm \mathrm{SE})$ & $\mathrm{PP}$ & $(\mathrm{X} \pm \mathrm{SE})$ & PP \\
\hline Kontrol & $75,00 \pm 2,12$ & & $106,50 \pm 4,05$ & & $157,25 \pm 16,06$ & & $202,00 \pm 26,06$ & \\
\hline $\mathrm{LC}_{50}(0,14 \%)$ & $70,00 \pm 0,41$ & $7 \%$ & $86,75 \pm 12,31$ & $19 \%$ & $128,25 \pm 27,10$ & $18 \%$ & $129,50 \pm 28,63$ & $36 \%$ \\
\hline $1,5 \times \mathrm{xC}_{50}(0,21 \%)$ & $69,25 \pm 3,09$ & $8 \%$ & $93,25 \pm 7,97$ & $12 \%$ & $153,00 \pm 22,94$ & $3 \%$ & $173,25 \pm 34,50$ & $14 \%$ \\
\hline $2 \mathrm{xLC}_{50}(0,28 \%)$ & $72,50 \pm 0,65$ & $3 \%$ & $91,00 \pm 12,13$ & $15 \%$ & $117,25 \pm 17,21$ & $25 \%$ & $138,75 \pm 15,27$ & $31 \%$ \\
\hline $2,5 \times x^{2} C_{50}(0,35 \%)$ & $71,50 \pm 2,87$ & $5 \%$ & $89,00 \pm 3,19$ & $16 \%$ & $121,00 \pm 10,55$ & $23 \%$ & $134,50 \pm 13,51$ & $33 \%$ \\
\hline $3 \times \mathrm{LC}_{50}(0,42 \%)$ & $72,00 \pm 0,82$ & $4 \%$ & $91,75 \pm 6,42$ & $14 \%$ & $133,50 \pm 15,28$ & $15 \%$ & $152,75 \pm 15,67$ & $24 \%$ \\
\hline
\end{tabular}

\begin{tabular}{|c|c|c|c|c|c|c|c|c|c|c|}
\hline \multirow{3}{*}{ Perlakuan } & \multicolumn{10}{|c|}{ Rata-rata jumlah populasi Aphis gossypii (ekor/tan) pada HSA } \\
\hline & \multicolumn{2}{|c|}{$\begin{array}{c}\text { Aplikasi ke-2 } \\
4^{\text {th }} \\
\end{array}$} & \multicolumn{2}{|c|}{$5^{\text {tn }}$} & \multicolumn{3}{|c|}{6} & \multicolumn{3}{|c|}{7} \\
\hline & $(\mathrm{X} \pm \mathrm{SE})$ & $\mathrm{PP}$ & $(\mathrm{X} \pm \mathrm{SE})$ & $\mathrm{PP}$ & $(\mathrm{X} \pm \mathrm{SE})$ & & PP & $(\mathrm{X} \pm \mathrm{SE})$ & & PP \\
\hline Kontrol & $265,25 \pm 43,29$ & & $255,00 \pm 50,86$ & & $355,00 \pm 67,57$ & $\mathrm{~b}$ & & $311,25 \pm 71,76$ & $\mathrm{~b}$ & \\
\hline $\mathrm{LC}_{50}(0,14 \%)$ & $219,50 \pm 19,68$ & $17 \%$ & $195,25 \pm 29,50$ & $27 \%$ & $249,00 \pm 13,06$ & $\mathrm{ab}$ & $30 \%$ & $182,75 \pm 31,95$ & $\mathrm{a}$ & $41 \%$ \\
\hline $1,5 \times \operatorname{xC}_{50}(0,21 \%)$ & $206,00 \pm 25,62$ & $22 \%$ & $192,00 \pm 27,00$ & $28 \%$ & $211,50 \pm 25,11$ & $\mathrm{a}$ & $40 \%$ & $124,25 \pm 31,90$ & $\mathrm{a}$ & $60 \%$ \\
\hline $2 x C_{50}(0,28 \%)$ & $185,00 \pm 28,43$ & $30 \%$ & $168,00 \pm 26,30$ & $37 \%$ & $187,25 \pm 32,08$ & $\mathrm{a}$ & $47 \%$ & $133,50 \pm 23,30$ & $\mathrm{a}$ & $57 \%$ \\
\hline $2,5 \times \operatorname{LC}_{50}(0,35 \%)$ & $182,50 \pm 9,95$ & $31 \%$ & $159,50 \pm 28,93$ & $40 \%$ & $190,25 \pm 29,60$ & a & $46 \%$ & $127,75 \pm 28,16$ & $\mathrm{a}$ & $59 \%$ \\
\hline $3 x C_{50}(0,42 \%)$ & $177,50 \pm 16,43$ & $33 \%$ & $157,50 \pm 38,60$ & $41 \%$ & $158,00 \pm 28,81$ & $\mathrm{a}$ & $55 \%$ & $125,50 \pm 47,20$ & $\mathrm{a}$ & $60 \%$ \\
\hline
\end{tabular}




\begin{tabular}{|c|c|c|c|c|c|c|c|c|c|c|c|c|}
\hline \multirow{3}{*}{ Perlakuan } & \multicolumn{12}{|c|}{ Rata-rata populasi Aphis gossypii (ekor/tan) pada HSA } \\
\hline & \multicolumn{3}{|c|}{$\begin{array}{c}\text { Aplikasi ke-3 } \\
8 \\
\end{array}$} & \multicolumn{3}{|c|}{9} & \multicolumn{3}{|c|}{10} & \multicolumn{3}{|c|}{11} \\
\hline & $(\mathrm{X} \pm \mathrm{SE})$ & \multicolumn{2}{|c|}{ PP } & $(\mathrm{X} \pm \mathrm{SE})$ & & \multirow[t]{2}{*}{ PP } & $(\mathrm{X} \pm \mathrm{SE})$ & & \multirow[t]{2}{*}{$\mathrm{PP}$} & \multicolumn{2}{|l|}{$(\mathrm{X} \pm \mathrm{SE})$} & \multirow[t]{2}{*}{$\mathrm{PP}$} \\
\hline Kontrol & $343,00 \pm 61,70$ & $\mathrm{~b}$ & & $375,00 \pm 76,76$ & $\mathrm{~b}$ & & $381,50 \pm 96,71$ & $\mathrm{~b}$ & & $455,75 \pm 107,75$ & $\mathrm{~b}$ & \\
\hline $\mathrm{LC}_{50}(0,14 \%)$ & $222,00 \pm 18,87$ & $\mathrm{ab}$ & $35 \%$ & $232,75 \pm 19,04$ & $\mathrm{ab}$ & $38 \%$ & $143,50 \pm 16,30$ & a & $62 \%$ & $188,00 \pm 22,32$ & a & $59 \%$ \\
\hline $1,5 x C_{50}(0,21 \%)$ & $126,25 \pm 46,05$ & $\mathrm{a}$ & $63 \%$ & $147,00 \pm 44,04$ & $\mathrm{a}$ & $61 \%$ & $71,00 \pm 28,96$ & $\mathrm{a}$ & $81 \%$ & $124,00 \pm 37,91$ & a & $73 \%$ \\
\hline $2 \mathrm{xLC}_{50}(0,28 \%)$ & $143,25 \pm 25,37$ & $\mathrm{a}$ & $58 \%$ & $141,75 \pm 23,76$ & $\mathrm{a}$ & $62 \%$ & $106,25 \pm 32,61$ & $\mathrm{a}$ & $72 \%$ & $111,50 \pm 22,90$ & a & $76 \%$ \\
\hline $2,5 \mathrm{xLC}_{50}(0,35 \%)$ & $118,25 \pm 34,37$ & $\mathrm{a}$ & $66 \%$ & $110,75 \pm 27,79$ & $\mathrm{a}$ & $70 \%$ & $87,25 \pm 39,48$ & $\mathrm{a}$ & $77 \%$ & $89,25 \pm 28,00$ & a & $80 \%$ \\
\hline $3 \times \mathrm{xLC}_{50}(0,42 \%)$ & $140,75 \pm 53,94$ & $\mathrm{a}$ & $59 \%$ & $108,50 \pm 39,33$ & $\mathrm{a}$ & $71 \%$ & $114,75 \pm 61,29$ & $\mathrm{a}$ & $70 \%$ & $88,00 \pm 34,95$ & $\mathrm{a}$ & $81 \%$ \\
\hline \multirow{3}{*}{ lakuan } & \multicolumn{12}{|c|}{ Rata-rata populasi Aphis gossypii (ekor/tan) pada HSA } \\
\hline & \multicolumn{3}{|c|}{$\begin{array}{c}\text { Aplikasi ke-4 } \\
12 \\
\end{array}$} & \multicolumn{3}{|c|}{13} & \multicolumn{3}{|c|}{14} & \multicolumn{3}{|c|}{15} \\
\hline & $(\mathrm{X} \pm \mathrm{SE})$ & & $\mathrm{PP}$ & $(\mathrm{X} \pm \mathrm{SE})$ & & $\mathrm{PP}$ & $(\mathrm{X} \pm \mathrm{SE})$ & & $\mathrm{PP}$ & $(\mathrm{X} \pm \mathrm{SE})$ & & $\mathrm{PP}$ \\
\hline Kontrol & $483,50 \pm 113,42$ & $\mathrm{~b}$ & & $591,25 \pm 145,93$ & $\mathrm{~b}$ & & $708,00 \pm 201,17$ & $\mathrm{~b}$ & & $664,00 \pm 209,87$ & $\mathrm{~b}$ & \\
\hline $\mathrm{LC}_{50}(0,14 \%)$ & $158,00 \pm 18,03$ & $\mathrm{a}$ & $67 \%$ & $194,50 \pm 25,22$ & $\mathrm{a}$ & $67 \%$ & $206,75 \pm 36,77$ & $\mathrm{a}$ & $71 \%$ & $141,50 \pm 38,47$ & $\mathrm{a}$ & $79 \%$ \\
\hline $1,5 x C_{50}(0,21 \%)$ & $122,00 \pm 52,42$ & $\mathrm{a}$ & $75 \%$ & $128,25 \pm 47,80$ & $\mathrm{a}$ & $78 \%$ & $133,75 \pm 41,81$ & $\mathrm{a}$ & $81 \%$ & $124,25 \pm 37,93$ & $\mathrm{a}$ & $81 \%$ \\
\hline $2 \mathrm{xLC}_{50}(0,28 \%)$ & $104,00 \pm 26,50$ & $\mathrm{a}$ & $78 \%$ & $129,50 \pm 34,99$ & $\mathrm{a}$ & $78 \%$ & $104,00 \pm 15,38$ & $\mathrm{a}$ & $85 \%$ & $82,00 \pm 22,46$ & $\mathrm{a}$ & $88 \%$ \\
\hline $2,5 x C_{50}(0,35 \%)$ & $63,50 \pm 22,15$ & $\mathrm{a}$ & $87 \%$ & $64,50 \pm 19,45$ & $\mathrm{a}$ & $89 \%$ & $46,00 \pm 11,78$ & $\mathrm{a}$ & $94 \%$ & $43,75 \pm 12,09$ & a & $93 \%$ \\
\hline $3 \mathrm{xLC}_{50}(0,42 \%)$ & $57,50 \pm 22,47$ & $\mathrm{a}$ & $88 \%$ & $71,00 \pm 29,28$ & $\mathrm{a}$ & $88 \%$ & $65,75 \pm 23,86$ & $\mathrm{a}$ & $91 \%$ & $47,50 \pm 19,55$ & $\mathrm{a}$ & $93 \%$ \\
\hline
\end{tabular}

Keterangan :

HSA : Hari setelah aplikasi

$\mathrm{X} \quad$ : Rata-rata populasi Aphis gossypii (ekor per tanaman)

SE $\quad:$ Standar error

PP : Penurunan populasi ((populasi kontrol-populasi perlakuan/populasi kontrol) x 100\%) Angka yang diikuti huruf yang sama pada setiap kolom tidak berbeda nyata menurut uji Duncan pada taraf $5 \%$

tn : tidak berbeda nyata 
Suhu di rumah kaca berkisar $25{ }^{\circ} \mathrm{C}-37{ }^{\circ} \mathrm{C}$. Hal ini merupakan suhu optimum bagi A. gossypii. Capinera (2018) menyebutkan bahwa suhu optimal reproduksi $A$. gossypii berkisar antara $21{ }^{\circ} \mathrm{C}-27{ }^{\circ} \mathrm{C}$. Imago A. gossypii dapat memproduksi tetesan madu, gula dan keturunan yang lebih tinggi pada suhu 26,7 ${ }^{\circ} \mathrm{C}$ dari pada suhu $15,6{ }^{\circ} \mathrm{C}$ atau $32,2{ }^{\circ} \mathrm{C}$. Hal lain yang mendukung peningkatan populasi $A$. gossypii yang cukup signifikan adalah sifat partenogenesis yang didukung juga dengan kondisi lingkungan yang optimal untuk reproduksi. Berdasarkan hal ini, faktor tersebut dapat dijadikan salah satu penyebab populasi yang fluktuatif selama percobaan.

Menurut Moekasan dkk (2015), ambang ekonomi kutu daun pada tanaman cabai yaitu 0,7 ekor/daun. Berdasarkan hal tersebut, apabila pada suatu tanaman dengan rata-rata jumlah daun 42, maka maksimal terdapat kutu daun sebanyak 30 ekor/tanaman. Perlakuan $2 \mathrm{xLC}_{50}, 2,5 \mathrm{xLC}_{50}$, dan $3 \mathrm{xLC}_{50}$ dengan jumlah kutu daun kurang dari 120 ekor/perlakuan pada 15 HSA (Tabel 2). Oleh karena itu, perlakuan tersebut berada di bawah ambang ekonomi. Hal ini menunjukkan bahwa aplikasi ekstrak air bungkil biji mimba sebanyak 4x dapat menekan populasi A. gossypii berada dibawah ambang ekonomi.

Meskipun demikian, dilihat dari segi efisiensi serta berdasarkan uji statistik bahwa perlakuan $1,5 \mathrm{xLC}_{50}$ sudah mampu menekan populasi $A$. gossypii. Tingginya penurunan populasi berbanding lurus dengan konsentrasi ekstrak air bungkil biji mimba yang digunakan. Semakin tinggi konsentrasi maka penurunan populasi juga semakin tinggi.

\section{Intensitas Kerusakan Daun Tanaman Cabai Merah}

Kerusakan daun pada tanaman cabai merah akibat serangan A. gossypii setelah aplikasi kedua yaitu pada 7 HSA menunjukkan hasil berbeda nyata antar perlakuan (Tabel 3). Setelah aplikasi pertama kerusakan daun pada perlakuan $2,5 \mathrm{xLC}_{50}$ dan $3 \mathrm{xLC}_{50}$ menunjukkan hasil berbeda nyata dengan perlakuan $\mathrm{LC}_{50}, 1,5 \times \mathrm{xC}_{50}$, namun tidak berbeda nyata dengan perlakuan $2 \mathrm{xLC}_{50}$. Kerusakan terendah ada pada perlakuan ekstrak air bungkil biji mimba dengan konsentrasi $3 \mathrm{xLC}_{50}$ yaitu 5,50\%.

Tabel 3. Persentase gejala kerusakan daun cabai merah oleh Aphis gossypii

\begin{tabular}{lcc}
\multirow{2}{*}{ Perlakuan } & \multicolumn{2}{c}{ Rata-rata intensitas kerusakan daun cabai merah oleh Aphis gossypii (\%) } \\
\cline { 2 - 3 } & $7 \mathrm{HSA}$ & $14 \mathrm{HSA}$ \\
\hline Kontrol & $29,50 \mathrm{~b}$ & $32,00 \mathrm{~b}$ \\
$\mathrm{LC}_{50}(0,14 \%)$ & $29,25 \mathrm{~b}$ & $31,50 \mathrm{~b}$ \\
$1,5 \times \mathrm{xC}_{50}(0,21 \%)$ & $24,00 \mathrm{~b}$ & $26,75 \mathrm{~b}$ \\
$2 \mathrm{xLC}_{50}(0,28 \%)$ & $15,25 \mathrm{ab}$ & $15,75 \mathrm{a}$ \\
$2,5 \mathrm{xLC}_{50}(0,35 \%)$ & $8,00 \mathrm{a}$ & $9,75 \mathrm{a}$ \\
$3 \mathrm{xLC}_{50}(0,42 \%)$ & $5,50 \mathrm{a}$ & $7,25 \mathrm{a}$ \\
\hline $\mathrm{Ke}$ & & \\
\hline
\end{tabular}

Keterangan : Angka yang diikuti huruf yang sama pada setiap kolom tidak berbeda nyata menurut uji Duncan pada taraf nyata $5 \%$

HSA : Hari setelah aplikasi

Setelah aplikasi keempat atau pada 14 HSA kerusakan daun meningkat sesuai perlakuan yang diberikan dan berbeda nyata antar perlakuan. Tingginya kepadatan populasi (Tabel 3) berpengaruh terhadap intensitas kerusakan daun tanaman cabai merah. Semakin tinggi populasi kutu daun maka semakin tinggi persentase kerusakan daun. Perlakuan 2,5x $\mathrm{LC}_{50}$ dan $3 \mathrm{xLC}_{50}$ menunjukkan hasil yang berbeda nyata dibandingkan dengan perlakuan yang lainnya. Persentase intensitas kerusakan daun tanaman cabai merah pada kontrol yaitu 32,00\% sedangkan pada perlakuan pemberian ekstrak air bungkil biji mimba dapat menekan persentase serangan lebih rendah dari kontrol. Perlakuan $3 \mathrm{xLC}_{50}$ memberikan hasil persentase intensitas kerusakan daun terendah yaitu 7,25\%. Kemampuan ekstrak bungkil mimba menekanan kerusakan pada tanaman cabai akibat serangan $A$. glicine selain karena aplikasi ekstrak mengakibatkan kematian serangga juga karena ekstrak mimba memiliki pengaruh penghambat makan dan gangguan pada sistem syaraf pendeteksi kimiawi (Dhra et al., 2018) Gejala serangan kutu daun dapat menyebabkan daun berkerut dan keriting, tanaman menjadi kerdil juga layu pada populasi $A$. gossypii yang tinggi, serta kutu daun dapat menularkan virus dari satu tanaman ke tanaman lainnya (Flint, 2013). Persentase kerusakan daun tanaman cabai merah yang diamati saat percobaan (Gambar 2).

Kutu daun menghasilkan embun madu dari hasil ekskresinya, embun madu tersebut disenangi oleh semut hitam dan semut merah (Gambar 3). Embun madu yang dihasilkan oleh kutu daun dapat memicu tumbuhnya embun jelaga (Capnodium sp.) yang dapat menutupi permukaan daun sehingga proses fotosintesis terhambat akibatnya kualitas 
tanaman cabai merah menjadi rendah (Febriyanti, 2010).

Selain perubahan pada daun, setiap perubahan instar muda ke instar yang lebih tua kutu daun menghasilkan eksuvia yang berwarna putih tertinggal di sekitar kutu daun tersebut, seperti di batang atau daun bahkan di tanah (Gambar 4). Eksuvia merupakan bagian kutikula yang ditinggalkan pada proses pergantian kulit.

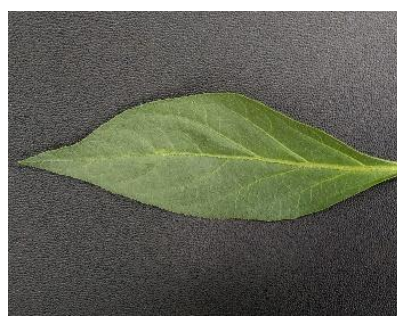

$0 \%$ (Kategori 0)

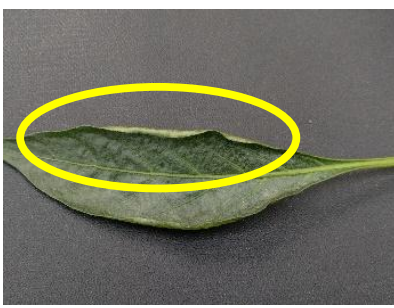

$45 \%$ (Kategori 3: $40 \%<\mathrm{x}<60 \%)$

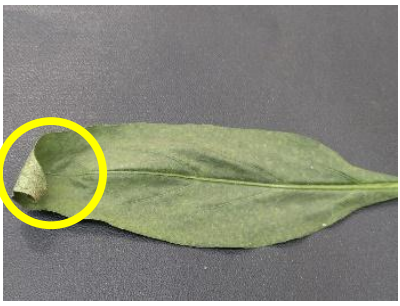

$5 \%$ (Kategori 1: $1 \%<x<20 \%)$

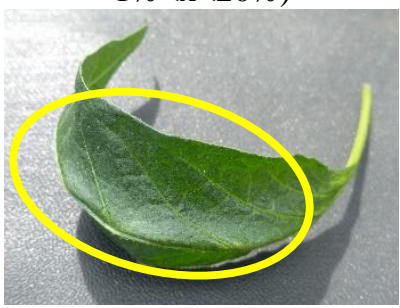

$70 \%$ (Kategori 4: $60 \%<\mathrm{x}<80 \%)$

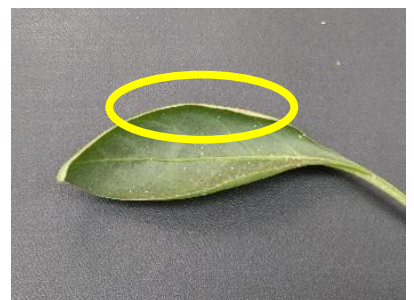

$25 \%$ (Kategori 2: $20 \%<\mathrm{x}<40 \%)$

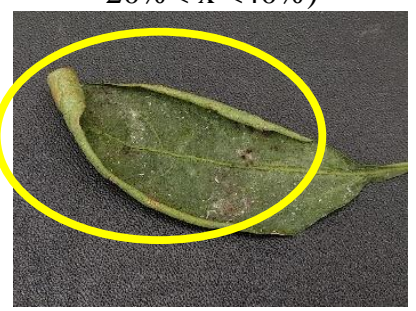

90\% (Kategori 5: $>80 \%)$

Gambar 2. Persentase kerusakan daun

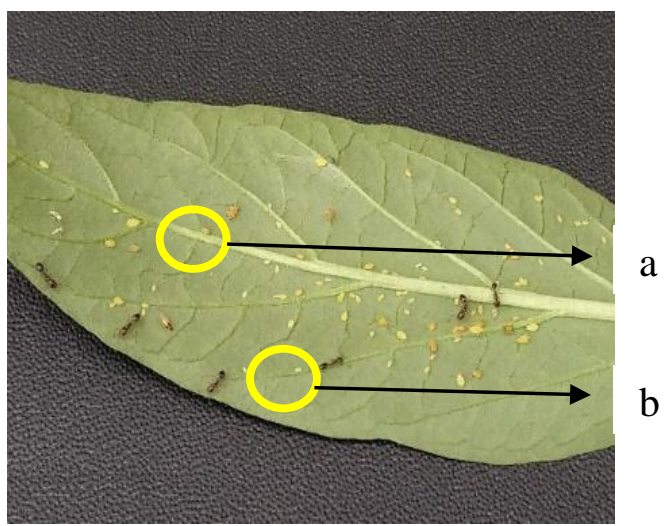

Gambar 3. Kutu daun yang bersimbiosis dengan semut; (a) Kutu daun, dan (b) Semut (Hymenoptera).

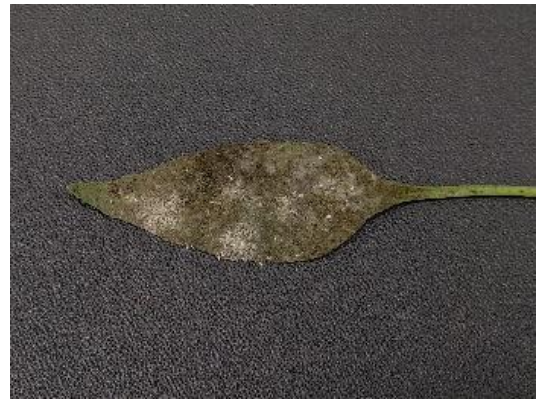

a

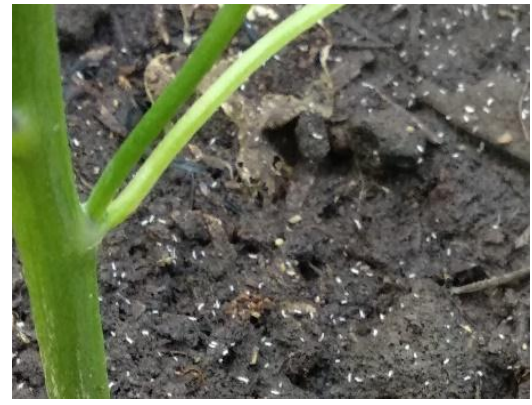

b

Gambar 4.Tanda serangan Aphis gossypii; (a) Terdapat embun jelaga, dan (b) eksuvia pada permukaan tanah 


\section{KESIMPULAN DAN SARAN}

Berdasarkan hasil penelitian, dapat diambil simpulan sebagai berikut :

1) Ekstrak air bungkil biji mimba bersifat toksik terhadap A. gossypii dengan nilai $\mathrm{LC}_{50}$ sebesar $0,14 \%\left(\mathrm{SK}_{95 \%} 0,011-0,313\right)$.

2) Aplikasi ekstrak air bungkil biji mimba konsentrasi $1,5 \mathrm{xLC}_{50} \quad(0,21 \%)$ dapat menekan populasi kutu daun A. gossypii pada tanaman cabai merah.

\section{ACKNOWLEDGEMENT}

Penelitian ini merupakan bagian penelitian berjudul produksi, standarisasi, legalisasi, dan pemasaran Formula insektisida botani ekstrak biji Azadirachta indica dan Barringtonia asiatica dengan peneliti utama Danar Dono yang dibiayai oleh program RAPID, Kementerian Riset, Teknologi, dan Pendidikan Tinggi. Kepada Kementerian Riset, Teknologi, dan Pendidikan Tinggi tim peneliti menyampaikan terima kasih.

\section{DAFTAR PUSTAKA}

Aziz MA, Shahzad AR, Naeem M, \& Shabbir G. 2014. Evaluation of Different Neem Product in Comparison with Imidacloprid Against Different Morphs of Mustard Aphid (Lipaphis erysimi Kalt.) on Canola Crop. Asian Journal Agri Biology 2(3): 191-201.

Badan Pusat Statistik (BPS). 2018. Statistik Tanaman Sayuran dan Buah-buahan Semusim Indonesia. Badan Pusat Statistik. Jakarta.

Capinera JL. 2018. Melon Aphid or Cotton Aphid, Aphis gossypii Glover (Insecta:Hemipter a:Aphididae). University of Florida EENY173.

Daryanto A, Syukur M, Maharijaya A, \& Hidayat P. 2017. Pewarisan Sifat Ketahanan Cabai terhadap Infestasi Aphis gossypii Glover (Hemiptera:Aphididae). Jurnal Hortikultura Indonesia 8(1):39-47.

Dewi AALN, Karta IW, Wati NLC, \& Dewi NMA. 2017. Uji Efektivitas Larvasida Daun Mimba (Azadirachta indica) terhadap Larva Lalat Sarcophaga pada Daging untuk Upakarya Yadnya di Bali. Jurnal Sains dan Teknologi. 6(1):126-135.

Dhra G, Ahmad M, Kumar J, \& Patanjali PK. 2018. Mode of action of Azadirachtin: A natural insecticide. Int. Res. J. Biological Sci. 7(12), 41-46.

Febriyanti. 2010. Kepadatan Populasi Kutu Daun (Aphis craccivora Koch) pada Tanaman Kacang Panjang di Kelurahan Kuranji Kecamatan Kuranji Padang. Jurnal sainstek 2(2):110-114.

George A, Rao CN, \& Rahangadale S. 2019. Current status of insecticide resistance in Aphis gossypii and Aphis spiraecola (Hemiptera:
Aphididae) under central Indian conditions in trus. Cogent Biology. 5: 1660494. https: //doi.org/10.1080/23312025.2019.1660494.

Kalshoven LGE. 1981. The Pest of Crops in Indonesia. Revised and Translated By P.A. Van der laan. Jakarta: PT. Ichtiar Baru-Van Hoeve.

Khodijah. 2014. Kelimpahan Serangga Predator Kutudaun Aphis gossypii di Sentra Tanaman Sayuran Sumatera Selatan. Biosaintifika 6(2).

Kilani-Morakchi S, Morakchi-Goudjil H, \& Sifi K. 2021.Azadirachtin-BasedInsecticide: Overview ,Risk Assessments, and Future Directions. Front. Agron. 3:676208. doi: 10.3389/fagro. 2021.676208.

Koch RL, Hodgson EW, Knodel JJ, Varenhorst AJ, \& Potter BD. 2018. Management of InsecticideResistant Soybean Aphids in the Upper Midwest of the United States. Journal of Integrated Pest Management. 9(1): 23; 1-7

Koul O, Isman MB, \& Ketkar CM. 1990. Properties and Uses of Neem, Azadirachta indica. Canadian Journal of Botany 68: 1-11.

Miles PW. 1987. Feeding Process of Aphidoidea in Relation to Effects on Thei Food Plants in Minks AK \& Harrewijn P (Eds.), Aphids: Their Biology, Natural Enemies and Control. Vol 2A. Elsevier:Amsterdam. pp.321-340.

Nurhayati. 2012. Virus Penyebab Penyakit Tanaman. Universitas Sriwijaya Press: Palembang. Pp 91.

Palupi D, Kusdiyantini E, Rahadian R, \& Prianto AH. 2016. Identifikasi Kandungan Senyawa Fitokimia Minyak Biji Mimba (Azadirachtin indica A. Juss). Jurnal Biologi 5(3): 23-28.

Purwanto, E. 2017. Kutu Aphis gossypii Glov pada Tanaman. Tersedia di http://agrokomplekskita .com/hama-kutu-aphis-gossypii-glov-pada-tan aman-inang/ (diakses 24/6/2018).

Samsudin. 2011. Biosintesa dan Cara Kerja Azadirachtin sebagai Bahan Aktif Insektisida Nabati. Prosiding Seminar Nasional Pestisida Nabati IV. Jakarta, 61-70 : Balai Penelitian Tanaman Rempah dan Aneka Tanaman Industri.

Satar S, Ulrich K, \& Uygun N. 1999. Development and Fecundity of Aphis gossypii Glover (Homoptera: Aphididae) of Three Malvaceae Hosts. Journal of Agriculture and Forestry 23:637-643.

Silva MS, Broglio SMF, Trindade RCP, Ferrreira ES, Gomes IB, \& Micheletti LB. 2015. Toxicity and Application of Neem in Fall Armyworm. Comunicata Scientiae 6(3):359-364.

Walker PT. 1991. Measurement of Insect Populations and Injury in Crop Loss Assessment and Pest Management (Teng, P.S.). APS Press the American Phytopathological Society. St. Paul Minnesota. Pp. 19-29.

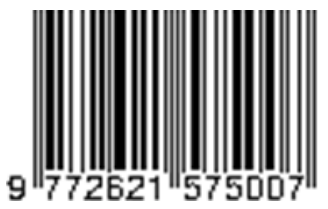

